\title{
PREPARATION OF POLISH POLICE OFFICERS FOR PEACE MISSIONS
}

\author{
Walentyna TRZCIŃSKA, PhD \\ w.trzcinska@wspol.edu.pl \\ Faculty of Police Applied Sciences \\ National Police Academy, Szczytno, Poland \\ Kamil KUĆ, M.A. \\ k.kuc@akademia.mil.pl \\ Faculty of National Security \\ War Studies University, Warsaw, Poland
}

\begin{abstract}
Conflicts in the 21st century have forced qualitative changes in the way of training missionary personnel. Police forces are currently used in various joint operations, which include, among others, elements of the fight against terrorism, ensuring the security of civilians and training of security forces. New types of operations require corrected preparation systems. This article analyses the previous way of preparing such units as Individual Police Officers, Specialized Police Teams, Formed Police Units, as well as the issue related to the training modification proposal, and one of them is the implementation of the virtual game "Gaming for Peace" as a supplement to the training gap through modern and more effective training.
\end{abstract}

Keywords: GAP, H2020, Gaming for peace, Gap Project, Police, Foreign missions, Training, Polish Police Contingent 


\section{Peacekeeping missions under the aegis of the UN}

International peace operations are a relatively new phenomenon. The first operation of this type ${ }^{1}$ (Koops Koops MacQueen Tardy Williams 2015, p. 1) is considered to be the deployment of military observers from the mandate of the UN Security Council in 1948 in the Middle East, whose task was to monitor the armistice in the Israeli-Arab conflict ${ }^{2}$ (United Nations, Department of Peacekeeping Operations, Department of Field Support n.d.). In 1949, the United Nations established the UN Group of Military Observers in India and Pakistan (UNMOGIP) (United Nations, Department of Peacekeeping Operations, Department of Field Support n.d.), operating in a similar manner. Both missions operate to this day and represent an observational and monitoring model of a peacekeeping mission. Military personnel serving in them perform their duties unarmed. In 1956 (the so-called Suez crisis) for the first time, besides observers, armed light infantry battalions were deployed within the First UN Emergency Force (UNEF I), established according to the resolution of the UN General Assembly to secure and to supervise the suspension of hostilities and the withdrawal of French, Israeli and British troops from Egypt, and then to separate the troops of Egypt and Israel $^{3}$ (Ośrodek Informacji ONZ in Warsaw n.d.). It was typically, as we might call it today, a mission for maintaining peace (peacekeeping) ${ }^{4}$.

1 Some authors see the beginnings of peacekeeping missions in the international military unit supervising on behalf of the League of Nations plebiscite in the Saarland in 1935.

2 The actions described led to the creation of the United Nations Truce Supervision Organization (UNTSO) that is still operating. In 1973, the UN forces in the region were extended by UNDOF (United Nations Disengagement Observer Force) in the Golan Heights, and in 1978 - UNIFIL (UN Interim Force in Lebanon); in the last two structures until 2011, Poles took part.

3 The mission operated until 1967. In 1973, the force was re-established at the request of Egypt, which is why it distinguishes between: UNEF I - 1956-1967 and UNEF II - 1973-1979.

4 The UN Secretary General, Butrus Butrus- Ghali in his 1992 An agenda for peace report, not only defined peace operations for the first time, but also created a fairly commonly accepted typology of them, distinguishing: preventive diplomacy, peacemaking (with the possibility of more involving peace enforcement), peacekeeping and peacebuilding. B. Boutros-Ghali, An agenda for peace, United Nations, New York, 1992. Police generally take part in the last types of tasks, which include actions aimed at creating and supporting political and social structures that consolidate peace and prevent the resumption of conflict. 
Although the $\mathrm{UN}$ is no longer the only organisation conducting peacekeeping operations $^{5}$, it is still the dominant entity in this field. From 1947 to 2013, out of 173 international peacekeeping missions in the world, the United Nations directly conducted 71 operations and authorised or approved 60; only 42 were deployed completely outside of it (Koops, Koops, MacQueen, Tardy, Williams, 2015, p. 20). More than one million military, police and civilian specialists from over 120 countries $^{6}$ (United Nations, Department of Peacekeeping Operations, Department of Field Support n.d.) have participated in the activities conducted under the aegis of the UN since 1948. Each UN peacekeeping mission is supervised by the UN Secretary-General and this supervision is exercised by a special envoy appointed by the Secretary and working directly at the mission site. Since 1992, the Secretary-General has been supported by two departments of the UN Secretariat: the Department of Political Affairs (DPA) and the Department of Peacekeeping Operations (DPKO). The first department focuses mainly on political activities and peacebuilding, the second deals with more extensive "uniformed" operations. In December 2017, about 93,000 military and police officers, supported by civilian personnel, served in 15 peace missions conducted under the aegis of DPKO and in 8 Special Political Missions under the aegis of the DPA. (United Nations Department of Peacekeeping Operations, Department of Field Support n.d.).

\section{Police officers on missions}

Officers of law enforcement institutions found themselves in the United Nations peacekeeping force for the first time in 1960. They were Canadian military policemen (Canadian Provost Corps) who, as part of the UN Organisation in Congo (ONUC), were supposed to propagate law and order on the streets of the capital of this newly created republic. In practice, such actions did not take place

5 The missions organised by regional international entities, such as the European Union, the Organisation of African Unity (since 2002 - the African Union), the OSCE, and various international coalitions play an increasing role.

6 Up to the end of 2017, 3,326 participants of peace-keeping missions died during service under the blue flag. 
due to the dramatic turnaround of the mission ${ }^{7}$ (United Nations, Department of Peacekeeping Operations, Department of Field Support n.d.). As a real-life component of the peacekeepers, the police officers entered the action for the first time in 1964, as part of the United Nations Peacekeeping Force in Cyprus (UNFICYP); this mission, as well as its police part, serve on the island of Aphrodite until today $^{8}$ (United Nations Security Council n.d.). Police officers have become an inseparable part of most peace missions, both those approved by the UN and those organised by other entities. According to data from December 2017, 11,387 police officers, including 1187 women (United Nations Department of Peacekeeping Operations Department of Field Support 2017 and United Nations, Department of Peacekeeping Operations, Department of Field Support n.d.), were serving in 11 missions administered by DPKO $^{9}$ and 5 missions administered by $\mathrm{DPA}^{10}$. In general, the proportions of the military and police participants of the UN mission are 10: 1, but there are both military/police and military-only missions, as well as police-only missions, such as MINUSTAH/ MINUJUSTH conducted since 2004 in Haiti.

Police officers serve on missions in three different modes:

- as members of organised police units; this is the most popular form of police service in peacekeeping missions;

- as individual police officers;

- as members of specialised teams ${ }^{11}$ (United Nations Department of Peacekeeping Operations Department of Field Support 2017).

7 The UN operation has become complicated as a result of the dynamically changing political situation in Congo and turned into a military operation on a large scale. At its peak, it engaged nearly 20,000 soldiers equipped with heavy weapons, armoured personnel carriers and military aviation. 250 uniformed and civilian peacekeepers died, including the United Nations Secretary-General, Dag Hammarskjöld.

8 In 2017, the police component of the Cypriot mission numbered 69 people, military 887. Report of the Secretary-General on United Nations Operations in Cyprus.

9 Haiti, Western Sahara, Liberia (mission completed March 30 ${ }^{\text {th }}, 2018$ ), Mali, Kosovo, Cyprus, Darfur, South Sudan, region of Abyei, Central African Republic, Democratic Republic of the Congo. Police officers do not participate in 4 missions administered by DPKO: UNTSO, UNDOF, UNIFIL (Middle East) and UNMOGIP (India / Pakistan), although there are military police officers participating in UNDOF and UNIFIL operations.

10 Colombia, Somalia, Guinea-Bissau, Afganistan, Libya.

11 This document allows the creation of other types of organised units, which could include, for example, dog handlers, crime analysts, forensic science teams, river police or SWAT teams. 
Individual Police Officers (IPOs), called experts in the Polish terminology, are police officers or representatives of other law enforcement agencies, delegated by their countries to serve in the United Nations. They operate in the country of deployment as individual members of international teams and structures that do not consider the country of origin. They operate unarmed; often they are not accommodated in barracks. Their tasks go in two directions: collecting and analysing information related to security (capturing warning signals), and building, reforming and rebuilding law enforcement institutions in the host country. IPOs perform various services, including developing community policing among residents of camps for refugees and camps for people internally displaced; training national police officers, helping to build and to consolidate host country police systems, strengthening various types of investigations with their specialist knowledge, and helping national police fight international crime. They also deal with administration and logistics supporting other IPOs. (United Nations Police n.d. and United Nations Department of Peacekeeping Operations Department of Field Support 2017).

Specialised Police Teams (SPT) are groups consisting of experts from one country or a small number of countries, with skills in one of the specific areas such as community policing, combating dangerous crime or organized crime, combating gender-based violence and sexual crime ${ }^{12}$ (United Nations Police n.d.).

A Formed Police Unit (FPU) is, in a way, an intermediate link between unarmed IPOs and armed military units. They are like mobile/anti-riot units. They work where a show of force is needed, but where the intervention of the army would be excessive. They serve armed; they can operate even in a high-risk situation. The unit consists (at least in the case of UN forces) of 120 - 140 officers who were trained and exercised together before setting off on a mission. After such training, the FPUs as a unit are assessed and qualified for participation in the mission by representatives of the Organised Police Assessment Team (United Nations Police n.d.). In the country of mission, officers are housed in barracks / camps. Their tasks include primarily ensuring the safety of UN staff and facilities

12 For example, in Haiti as part of MINUSTAH, such teams provide organisational and training assistance in the area of combating sexual and gender crime; in Mali (MINUSMA) a specialised team strengthens the skills of the local police and gendarmerie in the fight against terrorism and international organised crime. 
(and, depending on the circumstances, representatives of local authorities and seats of institutions, e.g. courts); protection of public order, and protection of civilians under the mandate of a specific mission. If necessary, FPUs also provide support to policemen operating individually

The FPU was first used in 1999 in the UNMIK in Kosovo and the UNTAET in East Timor (in both places, the United Nations assumed full responsibility for law enforcement and public order). The organisation of the FPU depends on the requirements of a specific mission; the minimum version includes three components: command and operational (commander, deputy, platoon leaders, section leaders, duty officers, liaison officers, and operational officers), a logistics component, and an executive component (United Nations Department of Peacekeeping Operations Department of Field Support 2016).

\section{Training for UN police officers}

The training of UN police officers is based on standards and materials developed by the UN's Integrated Training Service (ITS) ${ }^{13}$ in partnership with Member States and their training institutions for mission participants and with Integrated Mission Training Centres (IMTC) ${ }^{14}$ (United Nations Peacekeeping Resource Hub n.d.).

In general, the training consists of two stages:

- Pre-deployment stage, in the sending country or international training centre;

- Post- deployment training at the mission site:

- mission-specific induction training, carried out upon arrival

- ongoing training (there are three types of such a trainings: multi-sectoral, specialised, as well as those on professional development and corporate governance).

13 ITS is one of the organisational structures of the UN Secretariat serving two departments at the same time: DPKO and the Department of Field Support (DFS).

14 The global UN training and conference centre for peacekeeping staff is in Brindisi (Italy), and the regional centre for Africa in Entebbe (Uganda). 
Some training can be given by e-learning. ITS prepares trainers from the sending countries and is even able to give training assistance in sending by itself as well as in deployment countries thanks to its own mobile training teams (United Nations Peacekeeping Resource Hub n.d.)

Pre-deployment training of mission police forces is modular in nature. The first module is universal; it applies to all civilian and uniformed participants of the mission. It consists in familiarising them with basic information on UN peacekeeping missions, their mandate tasks and broadly understood principles of ethics as well as the health and safety rules of an individual participant in the mission $^{15}$ (Integrated Training Service DPET/DPKO \& DFS 2017). The second module applies only to UN police officers - both IPOs and FPUs. It covers the following issues: tasks of police officers in peacekeeping missions, UN police and various legal systems, human rights standards in detention and arrest, human rights standards and force/coercive measures, field navigation, radio communication, road safety and driving with 4-wheel vehicles (in the case of FPU, the last subject only concerns drivers) ${ }^{16}$ (Integrated Training Service DPET/DPKO \& DFS 2017).

Further training content for individual officers and formed police units is differentiated due to the different tasks and circumstances of serving in both formations. Police officers preparing to serve as IPOs should learn topics such as the most important goals of the UN police and its key partners, reforming, restructuring and rebuilding law enforcement institutions; mentoring and consulting, community policing, mediation / negotiation, working with language assistants, and writing reports ${ }^{17}$. The recommended pre-deployment training time for an IPO should last at least 2 weeks.

The training module specific for the FPU units includes:

- Basics of police tactics (including basics of police techniques, self-defence, vehicle control, tactical movement in the field and in buildings, first aid, and coping with stress)

15 DPKO-DFS Core Pre-deployment Training Materials (CPTM 2017) for United Nations Peacekeeping Operations.

16 DPKO-DFS Core Pre-deployment Training Materials (CPTM 2017) for United Nations Peacekeeping Operations.

17 This way acting out of the group, IPOs receive elements of knowledge and skills in the case of FPU transferred only to commanding staff. 
- Weapon training

- Tactics in dealing with threats to public order

- Security of UN personnel and facilities (including check posts, patrols, protection of personnel and facilities, escorting convoys, and awareness of the risk of improvised explosive devices - IEDs)

- Support for high-risk police operations (evacuation of occupied rooms, rebellions in prison, and operations with helicopters)

The special module for the commanding staff (includes elements of human resources management, tactical English or French vocabulary, mediation, work with language assistants, report writing and contingent equipment.

It is recommended that the duration of a course should consider the skills and knowledge previously possessed; usually, it is anticipated as at least 6-10 weeks, or 240 - 400 hours. The special module for the FPU command staff should last a week ${ }^{18}$ (United Nations Police 2011). The sending countries have the option of extending the modules if they see it as appropriate. ITS also organises training for UN missions senior management staff.

When it comes to missions from the mandate of the European Union, the training looks similar, with obvious changes regarding the European legal and organisational environment.

It should be noted that training does not end with graduating from pre-deployment courses. Police officers of the FPU units already in the target country quite regularly perform common exercises with other contingents and other organisations. Individual police officers on missions also undergo ongoing training.

An interesting example of integrating and perfecting the preparation of international police forces for crisis management missions of the European Union, the United Nations, the African Union and other organisations may be EUPST II (European Union Police Services Training) project, planned for the years 2015 2018, financed to a significant extent by the European Union. As part of this project, international groups of police officers from countries involved hold a series of

18 Strategic Guidance Framework for International Police Peacekeeping (SGF), the DPKO/DFS Policy on United Nations Police in Peacekeeping Operations and Special Political Missions, February 2014. 
several days of exercises combining theoretical and practical elements related to the preparation of personnel for future coverage of various tasks in mission areas, as well as practical elements related to emergency situations associated with the risk of loss of life and health. Exercises take place in training institutions that prepare future participants of the selected countries' missions, including military training grounds, in conditions imitating a mission environment. Poland also participates in the project, and two of the exercises under the EUPST II project have already taken place at the Police School in Słupsk ${ }^{19}$.

\section{Polish police on missions}

In comparison with other countries, Poland is currently not an active participant in peacekeeping missions, especially when it comes to United Nations missions ${ }^{20}$ (United Nations, Summary of Troop...). In projects organised by other entities, we are slightly more visible, especially in the territory of former Yugoslavia, and especially in Kosovo (military KFOR under the aegis of NATO and police EULEX as the European Union mission), though contrary to popular belief, these numbers are not impressive. However, the Polish police unit in Kosovo is very much appreciated for its training and operational capabilities ${ }^{21}$.

Polish police have been participating in United Nations peacekeeping missions since 1992, when 30 Polish policemen performed tasks of observation and inspection, observance of human rights and assistance to international institutions in the distribution of humanitarian aid as part of the UN Protection Force in Yugoslavia (UNPROFOR). From that time until the end of 2017, Polish policemen found

19 Project continues the earlier EUPST Project from 2011-2013, which resulted in the training of 250 police and gendarmerie officers. See official documental of the project, Proyecto EUPST (European Police Services Training).

20 In June 2018, after only 5 Polish military experts served on UN missions (Democratic Republic of Congo, Western Sahara, Southern Sudan, Kosovo); it puts our country's activity in 107the place in the list of 124. The biggest contingents were: Ethiopia (8508), Bangladesh (7105), Rwanda (7086), India (6719), Pakistan (6003), and from Europe - Italy (1029), Germany (855) and France (744). The activity of China in peacekeeping missions is rising quickly.

21 When this article was being written, August 2018, the $28^{\text {th }}$ change of the Polish police unit was serving in Kosovo as part of the EULEX contingent. 
themselves in eight missions under the auspices of the UN: UNPROFOR - the former Yugoslavia (1992-1995); UNGCI - Iraq (1995-1996); UNTAES - Croatia (1996-1998), UNIPTF - Bosnia and Herzegovina (1996-2002), UNMOT - Tajikistan (1998-2000); UNMIK - Kosovo (199922-2008); UNOMIG - Georgia (2003-2009), Liberia (UNMIL) - 2004-2018 ${ }^{23}$ (United Nations Mission in the Sudan n.d.).

An additional $7 \mathrm{EU}$ missions should be added to this list: the already completed PROXIMA - Macedonia (2003-2005); EUPM - Bosnia and Herzegovina (2003 - 2012); AMIS II - Sudan (2005-2006); EUPOL - Afghanistan (2007-2016) and the ongoing: EUMM - Georgia (since 2008), EUAM - Ukraine (since 2015) and the largest of police missions, EULEX Kosovo (since 2008). Polish police officers also took part in two missions under the aegis of the OSCE: in Croatia (1998-2001) and OSCE SMM Ukraine (since 2016), and in the undertakings of the Western European Union (MAPE - Albania, 1997-2001) as well as the US Department of State in Iraq (2004 - 2005) ${ }^{24}$. In total, 3,518 policemen went through the international peace missions and operations by 2016, of which 2,873 served in EULEX - Kosovo ${ }^{25}$ (Komenda Główna Policji n.d.) During the deployment to serve in the mentioned contingents, 6 Polish policemen died and 52 were injured (Komenda Główna Policji n.d.).

\section{Pre-deployment training for Polish police officer candidates for peacekeeping missions}

There are three kinds of pre-deployment courses for officers - candidates for participants of peacekeeping missions included in the training offer for Polish police:

22 Although, initially, the mission of Polish policemen was of an expert nature, the officers were armed (Puławska 2016, p. 235).

23 According to (Puławska 2016, s. 233) Polish police officers participated in UNMIS in Sudan, but UNMIS data denies this (Poland is mentioned only as a country sending military officers) The author confused UNMIS and AMIS II, also in Sudan.

24 In fact, this training mission, the Polish Police Contingent for the Support of Iraqi Police Forces in the Republic of Iraq, took place in Jordan, at the International Center for Police Training.

25 According to information on this site, there were 107 Polish police officers on missions abroad in January 2018:100 in Kosovo, 3 in Georgia, 3 on Ukraine (2 - OSCE SMM Ukraine, 1 - EUAM Ukraine) and 1 in Liberia. 
- Specialist course preparing for service outside the country within police contingents as an expert (i.e. for IPO);

- Specialist course for police officers serving in formed police units within police contingents (for FPU members);

- Specialist course for the commanders of police contingents.

The course for future experts, police officers serving individually, is conducted in small, maximum twelve-person groups. Training does not prepare police officers for a specific mission in a specific country ${ }^{26}$, but generally for serving on foreign missions as an IPO. It consists of two stages: language training (4 weeks at the Higher Police School in Szczytno, currently an English or French language option) and 5 weeks of practical training at the CSP (Police Training Center) in Legionowo. The practical part includes 163 hours of classes for such topics as information on peace-keeping missions; rules for applying for positions in missions; principles of work in a multicultural and multi-ethnic environment; rules of behaviour in an area threatened by mine-pyrotechnic activity; psychophysical aspects of human functioning in connection with a mission; human rights and humanitarian law; monitoring, mentoring, and advising. It also includes the improvement of practical skills: off-road driving, use of maps and technical means of communication, and first aid. Courses for officers of police units (FPU-type) are conducted at the Police School in Słupsk for a specific mission and a specific change to it, and include an element of personnel selection: more officers participate in each of them then later go on the mission (as a result of evaluation during the course, about $10 \%$ of them are inscribed on the reserve list, but not on the main one). The training lasts 177 hours (22 training days) and includes three modules:

1. Legal and social as well as technical conditions for performing duties in the police unit within the police contingent (selected issues of service in police peace missions, human rights and humanitarian law, stress prevention, coping with difficult situations and elements of group psychology, first aid, technical means of communication and map reading skills, and rules of behaviour in an area threatened by mine-pyrotechnic action).

2. Activities of the police unit within the police contingent (use of direct coercive measures in peacekeeping, general and police drills, patrol duty on the

26 They undergo such training after arrival at the mission site as induction training. 
mission, rules and ways of using reinforcement, restoration of public order with reinforcement, tactics and techniques in police interventions and in antiterrorist operations, securing scenes of disasters and technical accidents.

3. Weapons training (including elements of preparatory and static shooting, fast, dynamic and situational shooting; use of shotguns and submachine guns)

According to the course programme, each group is assigned a missionary veteran as a mentor. He supervises the group and provides substantive advice to the trainees during classes and after them (Program kursu specjalistycznego...).

The course for police contingent commanders lasts $80 \mathrm{~h}$ (10 days) and includes three thematic blocks:

1. Organisational and legal aspects of commanding outside the country (regulations on the performance of tasks and the organisation of the police unit / contingent, human rights and humanitarian law, management of finances, equipment and material, and the technical documentation of actions taken by a commander during a mission).

2. Commanding a police contingent (psychological aspects of command in mission conditions, elements of management theory, and the basics of crisis management)

3. Improving English language skills while commanding a police contingent on a mission (Program kursu specjalistycznego...).

As you can see, Polish training is based on models developed for the United Nations, slightly modified according to the needs of the European Union (mainly in the area of legal and organisational aspects).

\section{Pre-deployment courses for candidates for peacekeeping missions evaluated by veterans of peacekeeping missions}

In April 2017, as part of the Gaming for Peace (GAP) project, which will be mentioned later, the authors of this publication carried out partially structured interviews on selected aspects of service on missions outside Poland with 15 officers (14 policemen and one Bureau of Government Protection (BOR) officer), participating in the past in such missions. The interview topics also 
included issues related to training before missions and the adequacy of the training in relation to the realities of the mission. Eleven respondents took part in missions only as part of a formed police unit, three within the unit and later as individual officers (IPO), and one - only as an individual officer operating in a small team (it was a BOR officer). All respondents passed the required training regulations before departure. Opinions on the quality of the training proved to be positive, while the assessment of the suitability of training for the needs of the mission differed depending on whether the service on the mission was later carried out within the police unit or team (positive evaluation) or individually (respondents considered the training insufficient).

Of course, members of the FPU, also in the first group, submitted some proposals for modifying the programme. Respondents focused on the need to expand the training elements of language training (both English and basic phrases in the local language of the deployment country), and preparations for the geographical and cultural environment of the deployment country: despite the lack of a separate topic in the training programme, the officers confirmed that before leaving, they were familiarised with the history and background of the conflict as well as the basic rules of behaviour in local culture, but from the perspective of later experiences, the respondents found this training insufficient, not reflecting the complexity of the situation, too oriented on warning against threats in place of taking positive aspects into account ${ }^{27}$. There were also proposals that the training should consider the problem of organising time after duty, which on the mission sometimes - when the days were less full of tasks - became a problem. Suggestions for changes also concerned the "hard skills" programme. One of the respondents, for example, pointed at the lack of such a topic as the procedures in the event of a mission participant being kidnapped (both the rules for acting in a hostage situation and in a situation when a colleague is taken hostage), which happened several times in Kosovo. Several people have suggested that the first aid training

27 All interviewed FPU veterans used to serve in Kosovo. Several times they stated: "we were warned that the Serbs are dangerous and hostile, and in fact it turned out that all this had been wrong".

There was also a suggestion that the lecturers should have really fresh experience, as the situation in Kosovo is changing rapidly and participating in the mission a few years earlier means outdated knowledge: "It would be nice if such activities were conducted by someone who was there during the last year. Because if there comes a guy who read books and was there 10 years ago, than on my part, pardon, thank you." 
should be modified, as the one proposed in the course is too basic and mainly covers commonly known matters ${ }^{28}$. As the most important positives of the training, the following were highlighted: the practical approach to the training, the participation of veterans from previous missions as trainers and mentors, and training activities being based on, as they were described, „European tactics” (that is the ones used by other units in the mission), which allowed the latter to side by side with other units, including the use of unified commands in English. The chance to get to know future contingent colleagues well, to unify ways for officers from different units and services to act, team integration, and rejection by the evaluation system of people isolating themselves from the team, for whom it would be hard to work and rest with for several months were all mentioned as positive elements ${ }^{29}$.

When it comes to the training for police officers participating in missions abroad as experts (IPO), although the training itself was judged by respondents as interesting, conducted by carefully selected experts and with use of relevant, i.e. practical, methods, respondents considered it did not prepare them fully for the mission. One of the respondents even initially refused to undergo such training before the deployment (but later recalled it), he only mentioned the induction training organised in place of the mission. What could be the reasons for this phenomenon? It seems this state of things can be influenced by several factors. Firstly, the course for experts is not carried out in terms of a specific mission. Inevitably, there are no elements regarding specific countries, their realities and cultures. These were presented to the respondents shortly before departure for a specific mission, but in a limited quantity, and what's more, up to this point, officers usually had managed to get most of the available information on their own. Secondly, the experts are much more in need of "soft" skills, knowledge of

28 Such were mainly the opinions of officers from SWAT teams, apparently better trained in this field than other officers.

29 Evaluation during the training is only one of several elements for selection of candidates for a mission as part of an FPU contingent. Candidates should meet formal criteria (be 25 years of age, with at least 5 years of uninterrupted service in the Police, possession of a driving licence at least category "B" for at least 2 years, and for commissioned officers knowledge of English at a minimum level of "B1").

During the recruitment process, candidates have a conversation with a psychologist, undergo a medical interview, pass a physical fitness test (and officers declaring skills in English - also an English language exam) and finally - they have an interview conducted by a qualifying team (Biuro Międzynarodowej Współpracy Policji 2017). 
the realities and culture of the deployment country and the ability to function in culturally diverse environments than the officers of the FPU, whose actions are often accurately operationalised with algorithms for different situations, and most of them every day, even abroad, work in the Polish environment, with the support of their Polish commanders and colleagues. The expert has only rather general guidelines, his work is based largely on getting information, negotiating, mitigating conflicts, and all or almost all colleagues come from other countries and cultures ${ }^{30}$. What's more, the expert sometimes, just after arriving, must take care of many things that the organisation provides to the officer from the FPU; for example, he has to find accommodation, and sometimes also a place in mission structures, to solve the matter of food etc. In general, an officer, even after completing a well-designed and excellently conducted course, may feel poorly prepared. In addition, the situation is aggravated by the fact that most Poles do not have extensive experience of functioning in a multi-ethnic and multicultural environment, which intensifies fears of differences and discourages applications for positions on expert missions ${ }^{31}$.

\section{Computer game as a remedy for the gap in soft skills training?}

Programmes for police training to prepare for participation in peacekeeping missions are usually the result of a kind of compromise between caring about achieving educational goals and caring about keeping costs as low as possible. Duration, size of groups, thematic scope, teaching methods and resources must often go to the back of the queue when the funds are limited. Soft skills often fall victim to such cuts. Lectures on management principles must replace teamwork training, talks (even if given by an expert in the subject), and familiarisation with complex aspects of a rich culture, and there is no space for learning positive aspects of diversity.

30 Respondents mentioned that even when several officers were going for the same mission they lacked integration or even the possibility to get to know each other -they met each other just before the departure, at the airport.

31 Maybe a remedy for such a feeling of incompleteness of preparation will be newly introduced extension of the course for experts with a language training module, including working with documents and forms used on missions. 
The idea of the research and development project Gaming for Peace, GAP, which inspired this article, is to identify gaps existing in training soft skills necessary to succeed in multicultural missions of the European Union after own research and analysis of the literature on best practices in training participants for international peacekeeping missions, and then designing an online role-playing game, which in an interesting, inexpensive way could help police and military officers become prepared to serve in real peace missions to practice these skills. The following key soft skills were identified: ability to communicate and to cooperate, skill of decision-making, sensitivity to cultural issues, sensitivity to gender issues, and stress management. The project is attended by representatives of academia, police and army as well as enterprises from Ireland, Northern Ireland, Finland, Portugal, Bulgaria and Poland.

The GAP project is part of wider trends in the use of so called technology of "serious games" designed to teach, train and sensitise people to prepare them for conflict prevention and peacebuilding. One can mention PeaceMaker, an online game designed for Arab and Israeli youth, allowing players to take the role of the other side of the conflict (Serious games - Peacemaker n.d.) or the IECEU (Improving the Effectiveness of Capabilities in EU Conflict Prevention) training platform, introducing six case studies based on EU missions and operations in Kosovo, Bosnia and Herzegovina, Afghanistan, Libya, the Congo, the Central African Republic and South Sudan and the Palestinian territories (IECEU n.d.) UNAOC, an association affiliated with the UN, even runs the PEACEapp competition for application and game developers for the best games created to generate new opportunities for intercultural dialogue and conflict prevention. The GAP project was financed (grant number 700670) by the European Union under the Horizon 2020 programme, and the game itself should be put into service by the end of 2018 .

\begin{tabular}{|l|l|l|}
\hline Mission & Number of police officers & Number of experts \\
\hline EU KOSOVO & 95 & 6 \\
\hline EUMM GEORGIA & 0 & 8 \\
\hline EUAM UKRAINE & 0 & 1 \\
\hline OSCE UKRAINE & 0 & 1 \\
\hline \multicolumn{2}{|l|}{} \\
\hline $\begin{array}{l}\text { Total number of peacekeepers } \\
\text { in 1992-2018 }\end{array}$ & 3825 (police officers and experts) \\
\hline
\end{tabular}

Table 1. Polish Police officers on peacekeeping missions (12.10.2018) 


\section{References}

Boutros-Ghali B., 1992. An agenda for peace. United Nations, New York

Biuro Międzynarodowej Współpracy Policji Komendy Głównej Policji, 2017. Postępowanie rekrutacyjne. Wydział Misji Zagranicznych i Oficerów Łącznikowych BMWP KGP [unpublished].

DPKO-DFS Core Pre-Deployment Training Materials for United Nations Peacekeeping Operations, 2017. [online] Available from: http://research.un.org/revisedcptm 2017 [Accessed 2 Mar 2018].

How to use the learning application? [online] Available from: http://www.ieceulearning. eu/?q=how-use-learning-application [Accessed 20 Feb 2018].

Komenda Główna Policji, Misje pokojowe [online] Available from : http://www.info. policja.pl/inf/wspolpraca-miedzynarod/misje-pokojowe/47732,Misje-pokojoweinformacje-ogolne.html [Accessed 10 Feb 2018].

Koops J., Koops J.A., MacQueen N., Tardy T., Williams P.D., 2015. The Oxford Handbook of United Nations Peacekeeping Operations. Oxford University Press, Oxford.

Louffer S., Hamacher J., ENTRi 2014. Handbook In Control: A Practical Guide For Civilian Experts Working In Crisis Management Missions, $2^{\text {nd }}$ edition. Center for International Peace Operation (ZIF), Berlin.

Ośrodek Informacji ONZ in Warsaw, 2012. UNEF I [online] Available from: http://www. unic.un.org.pl/misje_pokojowe/unefi.php [Accessed 5 Mar 2018].

Program kursu specjalistycznego dla policjantów pełniacych stużbę w jednostkach Policji w ramach kontyngentów policyjnych - „DJPKP” [unpublished].

Program kursu specjalistycznego dla kadry dowódczej kontyngentów policyjnych - „KDKP”. Decyzja Nr 115 Komendanta Gtównego Policji z dnia 27 lutego 2008 r. w sprawie programu kursu specjalistycznego dla kadry dowódczej kontyngentów policyjnych [unpublished].

Puławska K., 2016. Involvement of the Polish Police in international efforts to support peace. In D.S. Kozerawski (ed.), International peace and stabilization operations in Polish security policy in the 20th and 21st centuries., Akademia Obrony Narodowej, Warsaw.

STM Core Business of UN Police and Key Partners. [online] Available from: http:// repository.un.org/bitstream/handle/11176/387368/STM\%20Core\%20Business $\% 2$ 0of\%20UN\%20Police\%20and\%20Key\%20Partners.pdf? sequence=1\&isAllowed=y [Accessed 2 Mar 2018].

Serious games - Peacemaker. [online] Available from: https://www.youtube.com/ watch?v=7iPvWefuPwo [Accessed 10 Mar 2018].

UNMIS - United Nations Mission in the Sudan [online] Available from: https://peacekeeping. un.org/sites/default/files/past/unmis/facts.shtml [Accessed 5 Mar 2018]. 
United Nations Police, Individual Police Officers [online] Available from: https://police. un.org/en/individual-police-officers [Accessed 9 Apr 2018].

United Nations Police, 2011. Temporary Training Standards for Formed Police Units. [online] Available from: https://police.un.org/sites/default/files/fpu_training standards_2010.pdf [Accessed 9 May 2018].

United Nations, 2018. Summary of Troop Contributing Countries By Ranking Police, UN Military Experts on Mission, Staff Officers and Troop. [online] Available from: https:// peacekeeping.un.org/sites/default/files/2_country_ranking_2.pdf [Accessed 30 Jun 2018].

United Nations Security Council, 2017. Report of the Secretary-General on the United Nations operation in Cyprus. [online] Available from: http://www.un.org/ga/search/ view_doc.asp?symbol=S/2017/586 [Accessed 5 May 2018].

United Nations Department of Peacekeeping Operations Department of Field Support, 2017. Monthly Summary of Military And Police Contribution to United Nations Operations. 31 December [online] Available from: https://peacekeeping.un.org/sites/ default/files/msr_31_dec_2017_0.pdf [Accessed 4 Apr 2018].

United Nations Department of Peacekeeping Operations, Department of Field Support, 2016. Formed Police Units in United Nations Peacekeeping Operations. [online] Available from: https://police.un.org/sites/default/files/fpu_policy_2016.pdf [Accessed 15 Feb 2018].

United Nations, Department of Peacekeeping Operations, Department of Field Support, 2017. Guidelines: The role of United Nations police in protection of civilians. [online] Available from: https://police.un.org/sites/default/files/protection-of-civiliansunpol_guidelines_2017.pdf [Accessed 15 Feb 2018].

UN Peacekeeping, n.d., Our history. [online] Available from: https://peacekeeping.un.org/ en/our-history [Accessed 1 Mar 2018].

United Nations, n.d., Peacekeeping Resource Hub. [online] Available from: http://research. un.org/en/peacekeeping-community/training [Accessed 20 Feb 2018]. 